\title{
Sintesis dan Karakterisasi Senyawa-senyawa Hidroksi Ester Minyak Jarak Cina (Castrol Oil)
}

\author{
Parlan, Siti Marfu'ah, dan Yuyun Musabbikha \\ Jurusan Kimia, FMIPA \\ Universitas Negeri Malang \\ parlan.fmipa@um.ac.id
}

\begin{abstract}
Abstrak
Pemanfaatan minyak jarak cina (castrol oil) sebagai pelumas sangat terbatas, karena hanya digunakan pada mesin hidroulik. Hal ini disebabkan oleh viskositasnya yang tinggi. Selain itu, ikatan rangkap dalam minyak jarak cina mudah teroksidasi karena penyusun utama minyak jarak cina adalah asam risinoleat (asam 12hidroksi-cis-9-oktadekenoat). Pengubahan ikatan rangkap dalam minyak jarak menjadi gugus lain akan meningkatkan ketahanannya terhadap oksidasi. Penelitian ini bertujuan untuk mensintesis senyawa-senyawa hidroksi ester minyak jarak cina dengan mengubah ikatan rangkap pada asam lemaknya menjadi gugus hidroksil dan gugus ester. Penelitian ini terdiri dari dua langkah utama yaitu: 1) epoksidasi minyak jarak dengan asam peroksi format, dan 2) pembukaan cincin epoksida dengan asam format membentuk senyawa hidroksi ester. Analisis dan identifikasi senyawa hasil dilakukan dengan kromatografi lapis tipis dan spektrometri IR. Karakterisasi senyawa hasil sintesis menggunakan indeks bias dan viskositas. Hasil penelitian menunjukkan bahwa senyawa-senyawa hidroksi ester dapat disintesis dari minyak jarak cina melalui tahap pembentukan epoksida dan diikuti dengan pembukaan cincin epoksida dengan asam karboksilat. Berdasarkan karakter indeks bias dan viskositasnya diketahui bahwa senyawa hidroksi ester minyak jarak cina berpotensi digunakan sebagai pelumas Roda Gigi Industeri Standar AGMA (No. 8 untuk formil hidroksi ester dan No. 10 untuk propionil hidroksi ester).
\end{abstract}

Kata-kata kunci: hidroksi ester, epoksidasi, minyak jarak cina, pelumas.

\begin{abstract}
The utilization of castor oil as a lubricant is very limited, because it was only used on the machine hydraulic. This is because their highly viscosity. In addition, the double bond in ricinoleic acid (cys-12hydroxy-9-oktadecenoic acid) as the main constituent of castor oil is easily oxidized. The conversion of double bonds in the castor oil into another group will increase its resistance to oxidation. This research aims to synthesize the compounds of the hydroxyl ester derivatives of castor oil by converting the double bond in the fatty acid into hydroxyl and ester groups. This study consists of two main steps: 1) epoxidation of castor oil with performic acids, 2) opening of the epoxide ring with formic acid to form hydroxyl ester compound. Analysis and identification of the compounds is done by thin layer chromategraphy and infrared spectrometry. Characterization of compounds synthesized using the refractive index and viscosity. The results showed that the hydroxyl ester compounds can be synthesized from castor oil by epoxide double bonds and followed by ring opening of epoxides with carboxylic acids. Based on the character of the refractive index and viscosity is known that hydroxyl ester derivatives of castor oil could potentially be used as a lubricant of Gear Industries AGMA Standards (No. 8 for formic hydroxyl esters and No. 10 for propionic-hydroxyl esters).
\end{abstract}

Keywords: hydroxyl ester, epoxidation, lubricant

\section{PENDAHULUAN}

Minyak jarak (castrol oil) merupakan minyak nabati yang mudah diperoleh di Indonesia karena tanaman jarak sangat mudah dibudidayakan. Pemanfaatan minyak jarak di Indonesia saat ini terutama adalah sebagai bahan dasar pembuatan bahan bakar diesel (biodiesel) dan belum dilakukan kajian tentang fungsinya sebagai bahan pelumas.
Asam lemak utama (89\%) (Ogunniyi, 2006) minyak jarak adalah asam risinoleat (asam cis-12-hidroksi-9oktadekenoat).

Hingga saat ini bahan pelumas mesin dan kendaraan bermotor yang digunakan di Indonesia masih tergantung dan bersumber dari minyak bumi (petroleum). Minyak bumi merupakan sumberdaya 
alam yang keberadaannya terbatas dan tidak dapat diperbarui (unrenewable). Untuk mengurangi ketergantungan tersebut diperlukan upaya mencari alternatif pengganti yang berasal dari bahan yang dapat diperbarui (renewable).

Hampir semua pelumas dari minyak bumi (petroleum) merupakan pencemar lingkungan karena sifatnya yang tidak dapat diuraikan oleh mikroorganisme (Rhee, 1996). Sekitar 5-10 juta ton minyak bumi masuk ke biosfer, $40 \%$ di antaranya berasal dari tumpahan minyak, limbah industri dan rumah tangga, proses pemurnian, dan pengeboran lepas pantai. Oleh karena itu, diperlukan pelumas yang ramah lingkungan ("green lubricants") (Rhee, 1996) akibat meningkatnya jumlah pelumas yang masuk ke lingkungan, meningkatnya harga petroleum, dan ketatnya pengawasan terhadap kualitas lingkungan (Van Arnum, 2004 \& Viswanathan, 2005).

Salah satu bahan alternatif untuk mengatasi kedua masalah tersebut adalah minyak nabati (vegetable oil). Minyak nabati bersifat tidak mencemari lingkungan (biodegradable), merupakan sumber yang dapat diperbarui, dan harganya murah sebagai pengganti pelumas petroleum (Randles, 1992 \& Asadauskas, 1996). Beberapa turunan minyak nabati sangat berpotensi sebagai bahan pelumas (Loredana Pop, dkk., 2008). Penggunaan minyak nabati sebagai pelumas dalam industri dan transportasi merupakan satu upaya menyelamatkan lingkungan (Gawrilow, 2004).

Komponen utama asam-asam lemak minyak nabati adalah asam lemak tak jenuh (memiliki ikatan rangkap karbon-karbon). Adanya ikatan rangkap tersebut menyebabkan ketahanannya terhadap oksidasi rendah (mudah teroksidasi). Untuk meningkatkan ketahanan terhadap oksidasi maka dapat dilakukan transformasi menjadi gugus lain yang memiliki ketahanan oksidasi yang lebih tinggi. Tujuan penelitian ini adalah: 1) Mensintesis senyawa hidroksi ester minyak jarak cina dengan pereaksi asam format dan propionat, 2) Mengetahui karakter senyawa hidroksi ester minyak jarak hasil sintesis (indeks bias dan viskositas) dan kemungkinan pemanfaatannya sebagai bahan pelumas.

\section{METODE}

Penelitian ini merupakan penelitian eksperimental laboratoris dengan tujuan mendeversifikasi minyak jarak menjadi turunannya yaitu hidroksi ester diikuti dengan pengujian karakteristiknya yang meliputi parameter-parameter yang terkait dengan kegunaannya sebagai pelumas.
Penelitian ini secara umum meliputi 3 tahap, yaitu: 1) sintesis epoksida minyak jarak, 2) pembukaan epoksida minyak jarak dengan asam format dan asam propionat membentuk senyawa hidroksi ester, dan 3) penentuan karakteristik senyawa-senyawa hasil sintesis yang meliputi indeks bias dan viskositas.

Untuk mencapai tujuan penelitian seperti yang telah diuraikan sebelumnya, maka dilakukan beberapa tahapan penelitian eksperimen, yaitu:

\section{Tahap Pertama: Penyiapan Sampel}

Sampel yang diperlukan dalam penelitian ini adalah minyak jarak (castor oil) dan asam risinoleat. Sampel minyak jarak diperoleh dari PT Panadia Corporation dan PT Brataco Kimia di Malang.

\section{Tahap kedua: Sintesis/Pembuatan Hidroksi Ester Minyak Jarak}

\section{Reaksi Epoksidasi Minyak Jarak}

$\begin{array}{llllll}\text { Sebanyak 2,763 gram }(0,01 & \mathrm{mol}) & \mathrm{H}_{2} \mathrm{O}_{2}\end{array}$ dimasukkan ke dalam beaker glass, secara perlahanlahan ditambah dengan 0,816 gram asam format $(0,006$ mol), kemudian ditambahkan 3,078 gram ( \pm 0,001 mol) minyak jarak. Campuran tersebut kemudian distirer selama 16 jam pada suhu $4^{\circ} \mathrm{C}$. Setelah 10 jam, setiap 2 jam sekali campuran reaksi dianalisis dengan KLT. Setelah 16 jam campuran reaksi membentuk 2 fasa campuran, fasa air dan fasa organik. Kedua fasa ini kemudian dipisahkan. Fasa organik ditambah dengan $\pm 5 \mathrm{~mL}$ heksana dan dicuci dengan $5 \mathrm{~mL}$ akuades. Heksana di dalam larutan organik diuapkan di udara terbuka. Senyawa yang terbentuk kemudian diidentifikasi dengan spektrometer inframerah (IR).

\section{Pembentukan Hidroksi Ester}

Pada tahap ini sintesis hidroksi ester dilakukan dengan membuka cincin senyawa epoksida. Sebanyak 2,551 gram $( \pm 0,001 \mathrm{~mol})$ epoksida yang diperoleh pada tahap sebelumnya ditambah dengan 1,212 gram $( \pm 0.012 \mathrm{~mol})$ asam format dan direfluk selama \pm 6 jam pada suhu $100^{\circ} \mathrm{C}$ sambil diaduk Analisis senyawa hasil dengan KLT. KLT dilakukan setiap 1 jam sekali setelah jam ke-3. Setelah 6 jam reaksi membentuk 2 lapisan, lapisan atas (organik) dan lapisan bawah. Kedua lapisan dipisahkan. Lapisan organik kemudian ditambah dengan $5 \mathrm{~mL}$ aseton dan dibiarkan selama \pm 24 jam. Produk yang dihasilkan kemudian dicuci dengan $\pm 5 \mathrm{~mL}$ akuades. Kelebihan air pada sampel ditambah $\mathrm{Na}_{2} \mathrm{SO}_{4}$ anhidrat dan disaring. Setelah disaring dirotavapor pada suhu $\pm 40^{\circ} \mathrm{C}$. Hasil dari sintesis di atas kemudian diidentifikasi dengan spektrometer inframerah (IR). 


\section{Karakterisasi Sifat Fisika}

Indeks Bias

Pengukuran indeks bias dilakukan dengan menggunakan alat refraktometer Abbe. Refraktometer yang akan digunakan kacanya terlebih dahulu dibersihkan dengan tissue yang telah diberi alkohol agar permukaan prisma terbebas dari debu yang dapat menyebabkan kerusakan pada prisma. Alat terlebih dahulu dikalibrasi untuk mengetahui masih dalam keadaan baik atau tidak. Kalibrasi dilakukan dengan menggunakan akuades, hasil pengukuran indeks bias air adalah 1,3320. Sampel diteteskan pada prisma refraktometer Abbe. Pembacaan indeks bias dilakukan pada saat garis pisah terang gelap yang berada tepat pada posisi silang dari lensa pengamatan.

Harga pengukuran indeks bias menggunakan refraktometer Able dihitung menggunakan persamaan berikut.

$$
\mathrm{R}=\mathrm{R}^{\prime}+\mathrm{k}\left(\mathrm{T}^{\prime}-\mathrm{T}\right)
$$

$\mathrm{R}^{\prime}=$ skala pengukuran

$\mathrm{T}^{\prime}=$ suhu pengukuran

$\mathrm{T}=$ suhu kamar

$\mathrm{K}=$ faktor koreksi

$\mathrm{R}=$ indeks bias

\section{Viskositas}

Viskositas adalah ukuran yang menyatakan kekentalan suatu cairan atau fluida. Kekentalan merupakan sifat cairan yang berhubungan erat dengan hambatan untuk mengalir yang disebabkan oleh gesekan antar molekul. Beberapa cairan ada yang dapat mengalir cepat, sedangkan lainnya mengalir secara lambat.

Viskositas larutan dapat dihitung dengan membandingkan waktu yang diperlukan larutan sampel melewati pipa kapiler dengan waktu yang diperlukan pelarut melewati pipa kapiler. Viskositas larutan sampel dan pelarut murni sebanding dengan waktu pengaliran larutan dan pelarut. Dalam penelitian ini viskositas hasil sintesis ditentukan dengan viskosimeter Ostwald.

Perhitungan menggunakan persamaan:

$$
\frac{\eta_{1}}{\eta_{2}}=\frac{\rho_{1} t_{1}}{\rho_{2} t_{2}}
$$

$$
\begin{aligned}
\text { dengan: } & \\
\eta_{1} & =\text { Viskositas air }\left(\mathrm{Nsm}^{-2}\right) \\
\eta_{2} & =\text { Viskositas minyak }\left(\mathrm{Nsm}^{-2}\right) \\
\rho_{1} & =\text { Densitas air }(\text { gram } / \mathrm{mL}) \\
\rho_{2} & =\text { Densitas minyak }(\mathrm{gram} / \mathrm{mL}) \\
\mathrm{t}_{1} & =\text { Waktu alir air (sekon) } \\
\mathrm{t}_{2} & =\text { Waktu alir minyak (sekon) }
\end{aligned}
$$

\section{HASIL DAN PEMBAHASAN}

\section{Sintesis Hidroksi Ester Minyak Jarak}

Sintesis hidroksi ester dilakukan melalui dua tahap reaksi, yaitu reaksi epoksidasi dan pembukaan cincin epoksida. Kedua tahapan sintesis hidroksi ester minyak jarak cina dapat diuraikan sebagai berikut.

\section{Reaksi Epoksidasi Minyak Jarak}

Epoksidasi pada penelitian ini menggunakan metode seperti yang telah dilakukan oleh Brian, et al. (2007). Epoksidasi ini bertujuan untuk mengubah ikatan rangkap dalam minyak jarak menjadi epoksida. Epoksidasi dilakukan dengan mereaksikan minyak jarak dengan campuran asam format dan hidrogen peroksida. Pencampuran asam format dengan hidrogen peroksida bertujuan untuk menghasilkan asam performat yang bertindak sebagai pereaksi epoksidasi. Jadi asam performat dibuat "in situ".

Terbentuknya epoksida hasil reaksi epoksidasi dianalisis dengan KLT menggunakan eluen yang berupa campuran pelarut $n$-heksana, dietileter dan asam format dengan perbandingan 70:30:2. Analisis dilakukan setelah jam ke-10 setiap 2 jam sekali. Analisis dilakukan sampai besar noda produk konstan. Hasil sintesis diperkirakan adalah suatu senyawa dengan $R_{f} 0,64$ yang tercantum pada Gambar 1.

Setelah 16 jam, campuran pereaksi membentuk 2 lapisan yaitu fasa organik dan fasa air. Fasa organik berupa minyak yang berwarna putih dan kental. Minyak ini diduga sebagai minyak jarak yang telah terepoksidasi. Ke dalam campuran ditambahkan $n$ heksana untuk mengekstrak lapisan minyak dan kemudian dipisahkan dari lapisan air. Setelah dipisahkan dari fase airnya kemudian ditambahkan $n$-heksana. Lapisan $n$-heksana selanjutnya dievaporasi untuk menguapkan pelarutnya (nheksana). Hasil yang diperoleh berupa cairan kental tidak berwarna yang berbeda dengan minyak jarak asalnya (kuning pucat).

Pada reaksi epoksidasi minyak jarak digunakan pereaksi berupa asam peroksi karboksilat yang dibuat "in situ" dari reaksi antara asam karboksilat (asam format dan asam propionat) dan hidrogen peroksida. Reaksi pembentukan asam peroksiformat dari asam format dan hidrogen peroksida dituliskan sebagai berikut.

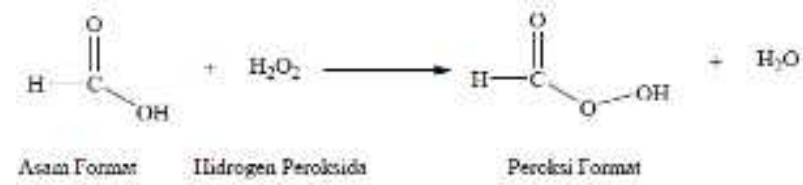


Persamaan reaksi epoksidasi minyak jarak cina (castrol oil) dapat dilihat pada Gambar 2. Senyawa dengan harga $R_{f}$ 0,64 yang diduga merupakan sebagai minyak hasil epoksidasi diidentifikasi gugus fungsinya dengan spektrometri IR. Hasil identifikasi tersebut dapat dilihat pada Gambar 3.

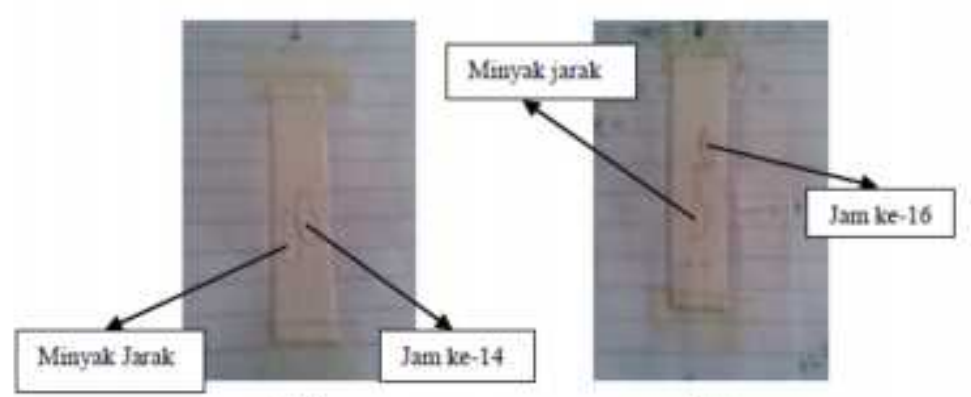

(a)

(b)

Gambar 1. Hasil Analisis KLT: (a) Hasil Pengadukan 14 Jam dan (b) Hasil Pengadukan 16 Jam

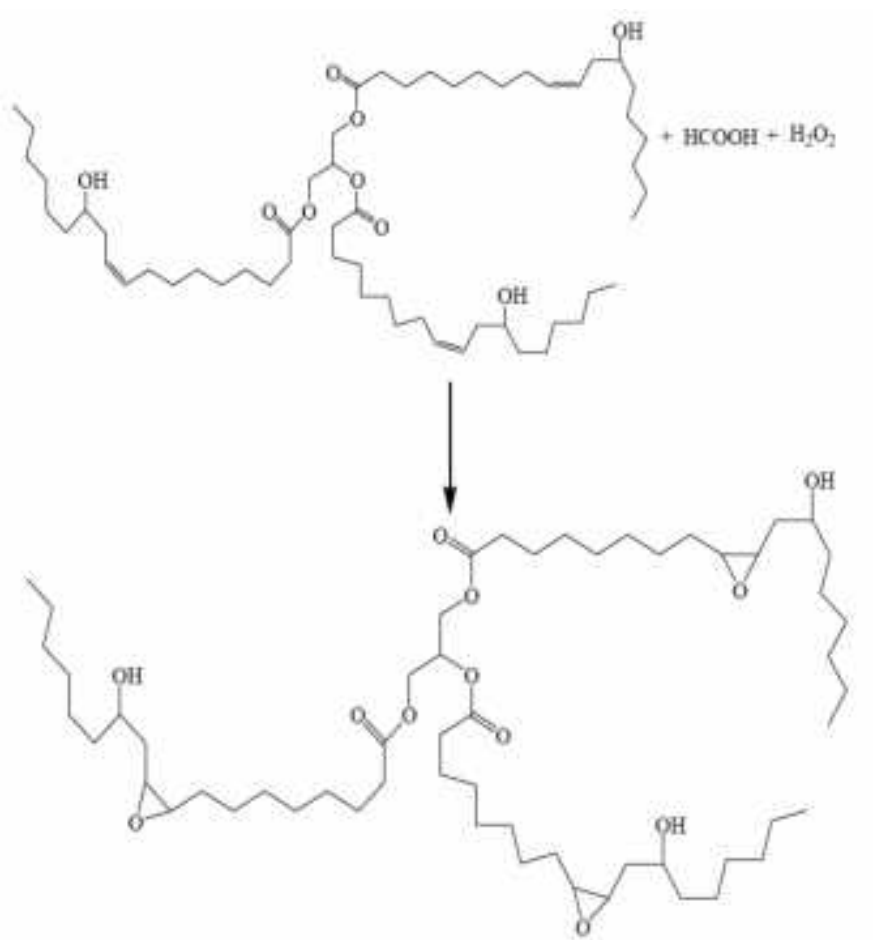

Gambar 2. Persamaan Reaksi Epoksidasi Minyak Jarak Cina dengan Asam Peroksi Format

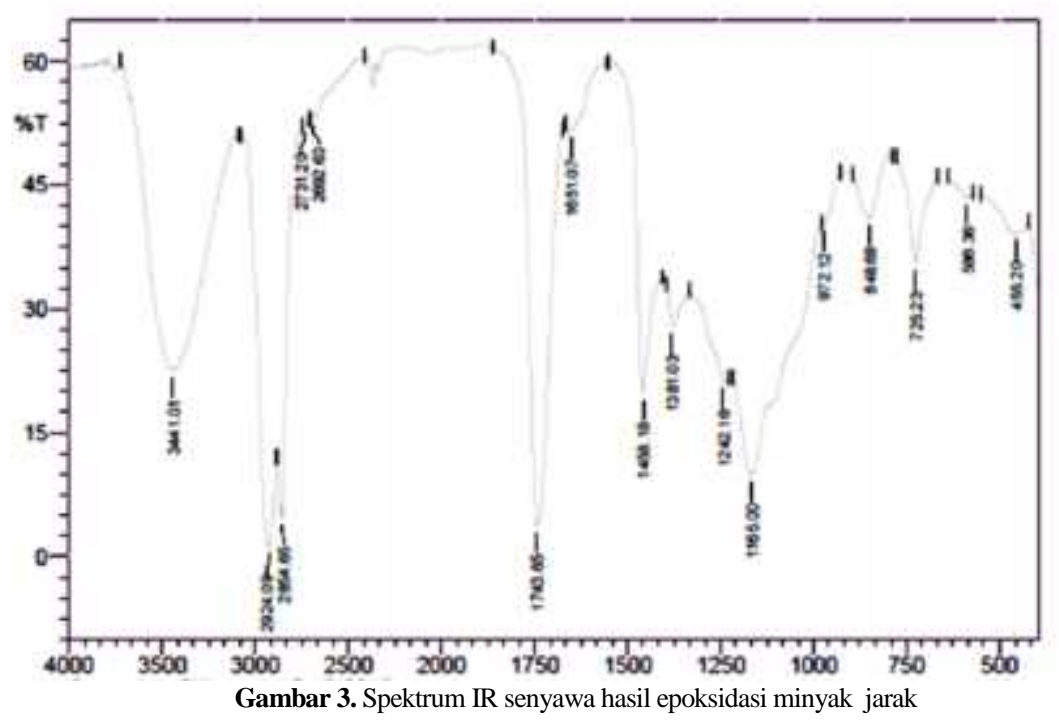


Spektrum inframerah hasil reaksi epoksidasi menunjukkan terbentuknya serapan tajam pada 2924,09 dan 2854,65 $\mathrm{cm}^{-1}$ yang menunjukkan adanya gugus metilen $\left(-\mathrm{CH}_{2}-\right)$ dan metil $\left(-\mathrm{CH}_{3}\right)$ yang diperkuat dengan adanya serapan pada 1458,18 dan $1381,03 \mathrm{~cm}^{-1}$. Serapan kuat pada $1743,65 \mathrm{~cm}^{-1}$ merupakan karakteristik untuk gugus $\mathrm{C}=\mathrm{O}$ (ester). Serapan yang melebar dan tajam pada daerah $3600-$ $3200 \mathrm{~cm}^{-1}$ menunjukkan adanya gugus $\mathrm{OH}$, serapan pada daerah $3441,01 \mathrm{~cm}^{-1}$ ini menunjukkan adanya gugus - $\mathrm{OH}$ alkohol. Pada 1242,16 dan 1165,00 $\mathrm{cm}^{-1}$ menunjukkan adanya gugus $\mathrm{C}-\mathrm{O}$ eter, daerah ini juga merupakan serapan untuk gugus epoksida yaitu pada daerah 1300-1050 $\mathrm{cm}^{-1}$ yang diperkuat dengan adanya serapan pada $848,68 \mathrm{~cm}^{-1}$ menunjukkan adanya cincin C-C. Tidak adanya serapan pada daerah 3000-3100 $\mathrm{cm}^{-1}$ menunjukkan tidak ada ikatan C-H rangkap. Ringkasan serapan IR hasil reaksi epoksidasi dapat dilihat dalam Tabel 1.

\section{Reaksi Pembentukan Hidroksi Ester dari Epoksida}

Senyawa hidroksi ester minyak jarak diperoleh dari reaksi pembukaan cincin epoksida minyak jarak yang telah diperoleh pada tahap sebelumnya. Pembukaan cincin epoksida dilakukan dengan menambahkan asam karboksilat (asam format dan asam propionat). Campuran direfluks pada suhu \pm $100{ }^{\circ} \mathrm{C}$ dengan pengadukan selama \pm 6 jam. Setelah 6 jam warna minyak berubah menjadi kuning pucat dan sedikit lebih encer. Terbentuknya senyawa hidroksi ester dianalisis dengan menggunakan metode kromatografi lapis tipis (KLT). Analisis dilakukan 1 jam sekali dimulai pada pemanasan jam ke-3. Hasil analisis menggunakan KLT menunjukkan bahwa harga $R_{f}$ senyawa hasil pembukaan cincin epoksida pada jam ke-6 sebesar 0,68 (berbeda dengan $R_{f}$ epoksida). Setelah jam ke-6 terbentuk dua lapisan. Pada lapisan minyak berwarna kunig pucat dan lapisan air kuning terang/jernih.

Dua lapisan yang terbentuk pada reaksi tersebut dipisahkan. Lapisan atas yang berwarna kuning pucat ditambah dengan aseton, dan dibiarkan selama \pm 24 jam. Campuran kemudian dicuci dengan akuades. Setelah fasa air dipisahkan, ekstrak yang diperoleh dikeringkan dengan menambahkan $\mathrm{Na}_{2} \mathrm{SO}_{4}$ anhidrat dan disaring. Untuk menguapkan aseton sisa pada sampel dilakukan penguapan dengan penguap putar atau rotavapor.

Selanjutnya lapisan minyak dipisahkan dan dianalisis dengan kromatografi lapis tipis (KLT). Kromatogram hasil reaksi pembukaan cincin epoksida tercantum pada Gambar 4.

Berdasarkan kromatogram Gambar 4 diketahui telah terbentuk senyawa baru $\left(R_{f}=0,68\right)$ yang berbeda dengan epoksida $\left(R_{f}=0,63\right)$. Senyawa tersebut diduga adalah senyawa hidroksi ester. Untuk membuktikan dugaan tersebut dilakukan identifikasi dengan spektrometri inframerah. Spektrum inframerah senyawa dengan $R_{f}=0,68$ ditunjukkan pada Gambar 5.

Spektrum IR untuk senyawa hasil pembukaan cincin epoksida menunjukkan serapan melebar antara 2200-3600 $\mathrm{cm}^{-1}$ yang merupakan serapan yang khas untuk gugus $-\mathrm{OH}$ terikat. Serapan pada $3448,72 \mathrm{~cm}^{-1}$ menunjukkan adanya gugus $-\mathrm{OH}$ (membentuk ikatan hidrogen), serapan yang tajam pada 2931,80 dan 2854,65 $\mathrm{cm}^{-1}$ menunjukkan adanya gugus metilen $\left(-\mathrm{CH}_{2}-\right)$ dan metil $\left(-\mathrm{CH}_{3}\right)$ yang diperkuat dengan adanya serapan pada 1458,18 dan $1381,03 \mathrm{~cm}^{-1}$. Serapan kuat pada $1720,50 \mathrm{~cm}^{-1}$ menunjukkan karakteristik dari gugus karbonil $(-\mathrm{C}=\mathrm{O})$. Pada rentang $1300-1050 \mathrm{~cm}^{-1}$ masih terlihat adanya serapan yang khas untuk gugus $\mathrm{C}-\mathrm{O}$ eter, tetapi puncak tajam pada daerah $848,68 \mathrm{~cm}^{-1}$ yang terlihat pada spektrum IR hasil epoksidasi (Gambar 4) tidak tampak. Secara keseluruhan terbukanya cincin epoksida ditandai dengan hilangnya serapan pada daerah $848,68 \mathrm{~cm}^{-1}$ yang merupakan serapan untuk cincin C-C. Ringkasan serapan IR hasil reaksi pembukaan cincin dapat dilihat dalam Tabel 2. Sedangkan perbedaan spektrum IR senyawa hasil reaksi epoksidasi dengan senyawa hasil pembentukan hidroksi ester disajikan pada Tabel 3.

Tabel 1. Ringkasan Serapan IR Hasil Reaksi Epoksidasi

\begin{tabular}{ccc}
\hline $\begin{array}{c}\text { Daerah serapan } \\
\text { teoritik }\left(\mathrm{cm}^{-1}\right)\end{array}$ & Daerah serapan senyawa $\left(\mathrm{cm}^{-1}\right)$ & Gugus \\
\hline $3100-2700$ & 2924,$09 ; 2854,65$ & $-\mathrm{CH}\left(\mathrm{sp}^{3}\right)$ \\
$1476-1430$ & 1458,18 & $-\mathrm{CH}\left(\mathrm{sp}^{3}\right)$ pada daerah sidak jari \\
& 1743,65 & $-\mathrm{C}=\mathrm{O}$ \\
$1750-1730$ & 3441,01 & $-\mathrm{OH}$ (alkohol) \\
$3600-3200$ & 1242,$16 ; 1165,00$ & $-\mathrm{C}-\mathrm{O}$ (eter, epoksida) \\
$1300-1050$ & 848,68 & $-\mathrm{C}-\mathrm{C}$ - (cincin) pada daerah \\
$900-800$ & & sidak jari \\
\hline
\end{tabular}




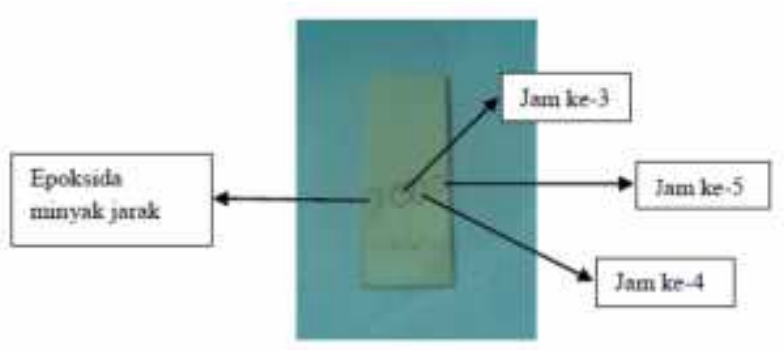

(a)

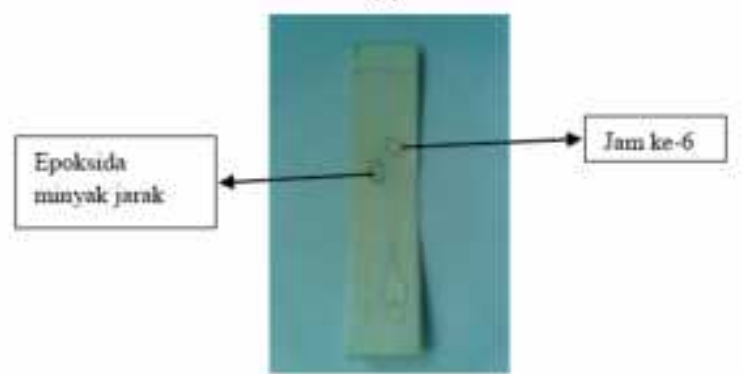

(b)

Gambar 4. Kromatogram Analis KLT Pembukaan Cincin Epoksida dengan Asam Format: (a) Hasil Pemanasan 3, 4, dan 5 jam (b) Hasil Pemanasan 5 dan 6 jam.

Tabel 2. Ringkasan serapan IR Hasil Reaksi Pembukaan Cincin Epoksida

\begin{tabular}{ccc}
\hline $\begin{array}{c}\text { Daerah serapan } \\
\text { teoritik }\left(\mathrm{cm}^{-1}\right)\end{array}$ & Daerah serapan setsyawa $\left(\mathrm{cm}^{-1}\right)$ & Gugus \\
\hline $3100-2700$ & $2931,80,2854,65$ & $-\mathrm{CH}\left(\mathrm{sp}^{3}\right)$ \\
$1476-1430$ & 1458,18 & $-\mathrm{CH}\left(\mathrm{sp}^{3}\right)$ pada daerah sidik jari \\
& 1720,50 & $-\mathrm{C}=\mathrm{O}$ \\
$1750-1730$ & 3448,72 & - OH (berikatan Hidrogen) \\
$3600-2500$ & 1280,44 & $-\mathrm{C}-\mathrm{O}$ (cter, epoksida) \\
$1300-1050$ & & \\
\hline
\end{tabular}

Tabel 3. Perbedaan antara Spektrum Inframerah Epoksida dan Senyawa Hidroksi Ester Minyak Jarak Cina

\begin{tabular}{lll}
\hline $\begin{array}{c}\text { Daerah serapan } \\
\text { teoritik }\left(\mathrm{cm}^{-1}\right)\end{array}$ & \multicolumn{1}{c}{ Epolssida Minyak Jarak } & \multicolumn{1}{c}{ Ester Mliuyak Jarak } \\
\hline $3600-2400$ & $\begin{array}{l}\text { Serapan melebar dan tajam pada } \\
\text { daerah 3441,01 } \mathrm{cm}^{-1} \text { menunjukkan } \\
\text { adanya gugus } \mathrm{OH} \text { alkohol }\end{array}$ & $\begin{array}{l}\text { Serapan melebar pada daerah antara } \\
3600-3200 \mathrm{~cm}^{-1} \text { menunjukkan adanya } \\
\text { gugus }-\mathrm{OH} \text { yang berikatan hidrogen. }\end{array}$ \\
$\begin{array}{l}\text { Se0-800 } \\
\text { Serapan lemah menunjulkkan } \\
\text { cincin epoksida }\end{array}$ & \\
\hline
\end{tabular}

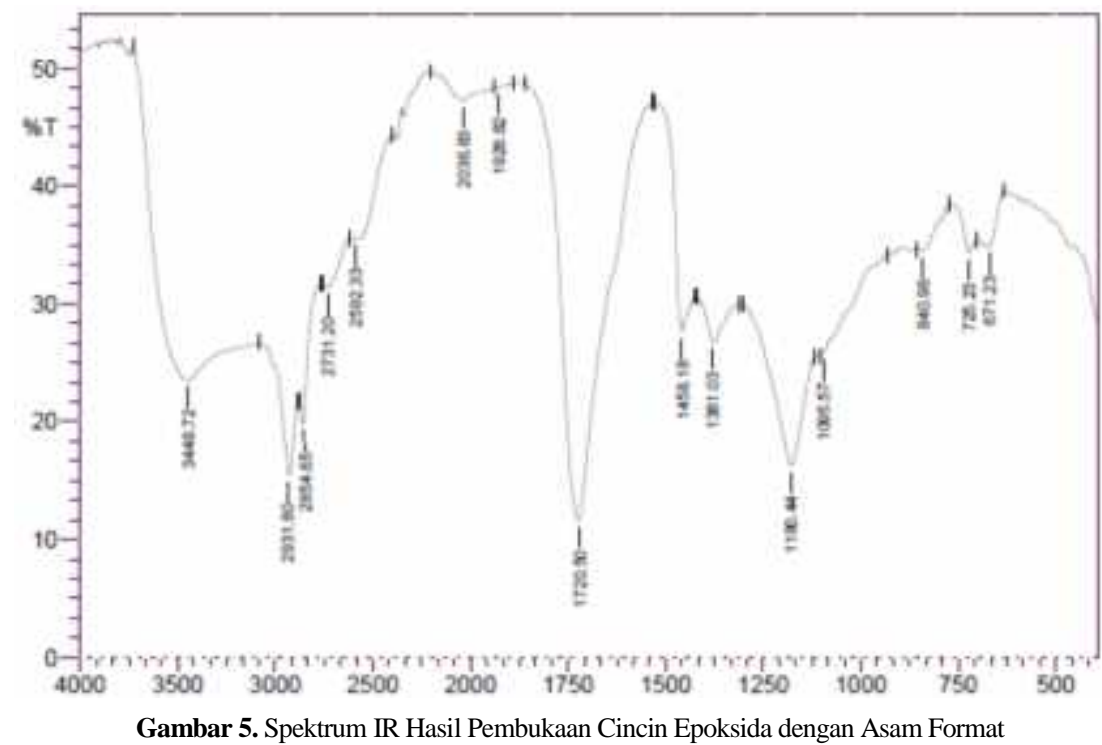




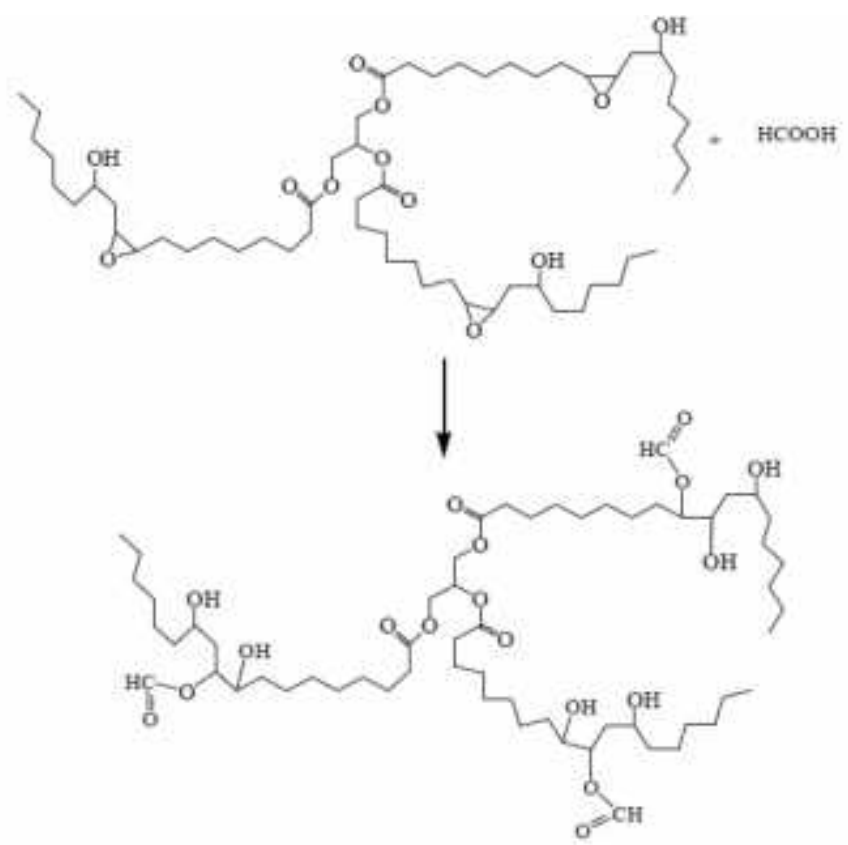

Gambar 6. Persamaan Reaksi Pembukaan Cincin Epoksida pada Minyak Jarak Cina (Castrol oil)

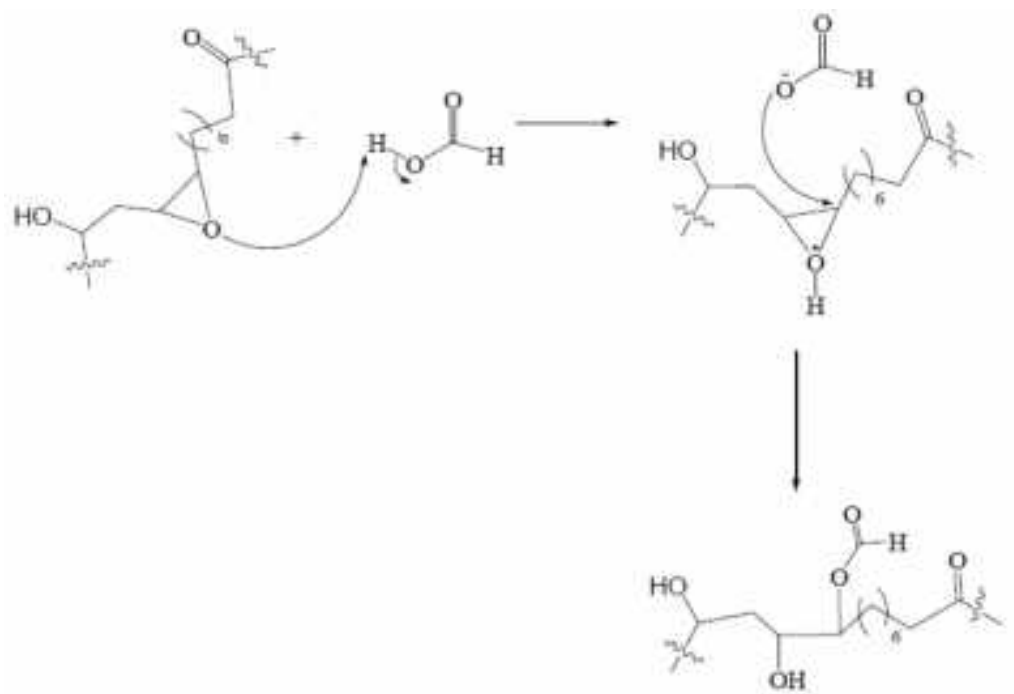

Gambar 7. Mekanisme Reaksi Pembukaan Cincin Epoksida

Reaksi pembukaan cincin epoksida merupakan reaksi substitusi nukleofilik. Reaksi ini diawali dengan pengaktifan epoksida oleh proton yang berasal dari nukleofil dengan katalis asam. Sumber nukleofil pada reaksi pembukaan cincin epoksida ini adalah asam format. Persamaan reaksi pembukaan cincin epoksida dengan asam format pada sintesis ini dapat dilihat pada Gambar 6 dan mekanisme reaksinya dapat dilihat pada Gambar 7.

\section{Karakterisasi Hasil Sintesis}

\section{Indeks Bias}

Indeks bias senyawa hasil diukur dengan menggunakan metode pembiasan pada prisma. Berkas laser ditembakkan pada prisma yang berisi minyak dengan berbagai variasi sudut datang, sampai ditemukan deviasi minimumnya. Deviasi minimum terjadi saat sudut datang sama dengan sudut bias. Wadah sampel yang digunakan sebagai tempat minyak terbuat dari kaca preparat. Indeks bias senyawa hidroksi ester disajikan pada Tabel 4.

Dari data pada Tabel 4 diketahui bahwa indeks bias senyawa hasil sintesis lebih kecil dari pada minyak jarak. Kerapatan senyawa hasil sintesis lebih tinggi dari pada minyak jarak sehingga kecepatan cahaya dalam minyak tersebut lebih kecil yang mengakibatkan nilai indeks biasnya lebih kecil (Sutiah, 2008). Molekul-molekul dalam minyak jarak memiliki banyak ikatan rangkap sehingga kerapatannya lebih kecil dan indeks biasnya lebih besar daripada senyawa hidroksi ester. 
Tabel 4. Indeks Bias Minyak Jarak dan Senyawa Hidroksi Ester Hasil Sintesis

\begin{tabular}{lc}
\hline \multicolumn{1}{c}{ Hidroksi Ester } & Indeks Bias $\left.\mathbf{( 2 5}^{\mathbf{0}} \mathbf{C}\right)$ \\
\hline Minyak Jarak & 1,477 \\
Formil hidroksi ester & 1,465 \\
Propionil hidroksi ester & 1,475 \\
\hline
\end{tabular}

\section{Viskositas}

Pengukuran viskositas dilakukan dengan viskosimeter Ostwald. Penetapannya dilakukan dengan jalan mengukur waktu yang diperlukan untuk mengalirnya minyak dalam pipa kapiler dari tanda atas (M1) ke tanda bawah (M2). Minyak hasil sintesis dimasukkan ke dalam viskosimeter. Minyak kemudian dihisap dengan pompa sampai di atas tanda M1. Cairan dibiarkan mengalir ke bawah dan waktu yang diperlukan dari M1 ke M2 dicatat menggunakan stopwatch. Dengan persamaan:

$$
\frac{\eta_{1}}{\eta_{2}}=\frac{\rho_{1} t_{1}}{\rho_{2} t_{2}}
$$

maka viskositas dari minyak hasil sintesis dapat ditentukan. Viskositas hidroksi ester hasil sintesis disajikan pada Tabel 5.

Viskositas minyak hasil sintesis lebih kental dari pada minyak jarak mula-mula $\left(589 \mathrm{cST}\right.$ pada $\left.25^{\circ} \mathrm{C}\right)$. Hal ini disebabkan oleh adanya gaya-gaya antarmolekul senyawa hidroksi ester lebih kuat dibandingkan dengan minyak jarak mula-mula. Meningkatnya kekuatan gaya antar molekul pada senyawa hidroksi ester minyak jarak disebebabkan dua faktor: 1) perubahan struktur rantai karbon pada adam lemak komponen utama (asam risinoleat) yang semula bengkok akibat adanya ikatan rangkap berubah menjadi ikatan tunggal yang linier, 2) meningkatnya ikatan hidrogen antar molekul akibat bertambahnya gugus hidroksil. Perubahan struktur rantai yang semula bengkok menjadi linier menyebabkan meningkatnya luas permukaan bidang sentuh antar molekul sehingga gaya van der waals-

\section{DAFTAR PUSTAKA}

Asadauskas, S., Perez, J.M., \& Duda, J.L. 1996. Oxidative stability and antiwear properties of high oleic vegetable oils. Lubr.Eng., 52(12), 877-882.

Brian, R.M., Brajendra, K.S., Kenneth, M.D., \& Sevim, Z.E. 2007. Diester From Olei Acid: Syntesis, Low Temperature Properties, and Oxidation Stability. JOCS, Journal of The American Oil Chemists' Society. Champaign: Juli 2007. Vol. 84, Iss. 7; pg. 675, 6 pgs.
Tabel 5. Viskositas Hidroksi Ester pada $25^{\circ} \mathrm{C}$ dan $40^{\circ} \mathrm{C}$

\begin{tabular}{|c|c|c|c|}
\hline \multirow[b]{2}{*}{ Hidroksi Ester } & \multicolumn{2}{|c|}{ Viskositas (cSt) } & \multirow{2}{*}{$\begin{array}{c}\text { Potensi sebagai } \\
\text { Pelumas Roda } \\
\text { Gigi Industri } \\
\text { Standar AGMA }\end{array}$} \\
\hline & $25^{\circ} \mathrm{C}$ & $40^{\circ} \mathrm{C}$ & \\
\hline Formil hidroksi ester & 846,8 & 787,4 & Pelumas No. 8 \\
\hline Propionil hidroksi ester & 3108,0 & 2890,0 & Pelumas No. 10 \\
\hline
\end{tabular}

nya juga semakin kuat. Semakin kuat gaya antarmolekul yang ada, maka zat akan makin sulit mengalir dan akibatnya kekentalannya semakin tinggi (Effendy, 2006).

Berdasarkan hasil pengukuran viskositas kinematic pada $40^{\circ} \mathrm{C}$, diketahui bahwa senyawa hidroksi ester minyak jarak cina berpotensi sebagai pelumas untuk roda gigi industry standar AGMA nomor 8 (formil hidroksi ester) dan nomor 10 (propionil hidroksi ester).

\section{KESIMPULAN}

Senyawa hidroksi ester minyak jarak cina dapat disintesis dari minyak jarak cina (castrol oil) melalui 2 tahap yaitu tahap reaksi epoksidasi ikatan rangkap pada minyak jarak pada suhu $4^{\circ} \mathrm{C}$ selama +16 jam dengan peroksiformat dan tahap pembukaan cincin epoksida dengan menggunakan asam format dan asam propionat pada suhu $100^{\circ} \mathrm{C}$ selama +6 jam. Senyawa hidroksi ester minyak jarak cina berpotensi digunakan sebagai pelumas Roda Gigi Industri Standar AGMA (no. 8 untuk formil hidroksi ester dan no. 10 untuk propionil hidroksi ester).

Untuk penelitian selanjutnya, perlu dilakukan pengukuran parameter-parameter lain yang terkait dengan syarat mutu pelumas sehingga spesifikasi kegunaan/pemanfaatan senyawa hidroksi ester sebagai pelumas dapat diketahui dengan lebih baik, serta upaya menurunkan viskositas senyawa hidroksi ester minyak jarak cina dengan mengubah gugus fungsi - OH menjadi gugus fungsi yang tidak membentuk ikatan hidrogen agar viskositasnya lebih rendah sehingga dapat dimanfaatkan sebagai pelumas mesin kendaraan bermotor.

Effendy. 2006. Teori Vsepr, Kepolaran dan Gaya Antarmolekul. Penerbit: Bayumedia Publishing.

Gawrilow I .2004. Vegetable oil usage in lubricants.

Loredana P. P, Bandur, C., Vlase, G., Gabriela. 2008. Basestock Oils for Lubricants from Mixtures of Corn Oil and Synthetic Diesters. Journal of the American Oil Chemists' Society v.85 no.1 pp. 93-94.

Stability. Journal of The American Oil Chemists Society, Vol. 84.Iss.7.pp.675. 
Ogunniyi, D.S. 2006. Castor Oil: a Vital Industrial Raw Material.Bioresour. Technol, 97: 10861091.

Randles, S.J. \& Wright M. 1992. Environmentally considerate ester lubricants for automotive and engineering industries. J. Synth.Lubr., 9, 145-161.

Rhee, I. S. 1996. Evaluation of environmentally acceptable hydraulicfluids. NLGI Spokesman, 60(5), 28-34.
Sutiah, K., Soffan, F., \& Wahyu, S.B. 2008. Studi Kualitas Minyak Goreng dengan Parameter Viskositas dan Indeks Bias. ISSN:1440-9662. Berkala Fisika, 11(2), 53-58.

Van Arnum P. Analysts say oil at $\$ 50$ per barrel is possible. Chem. Market Rep., 266, 1-2.

Viswanathan P. Oil price threat. Chem. Market Rep., 267,1 . 